\title{
Relationship of HR Practices and Career Path: A Perspective of Accounting Studies
}

\author{
Rizwan Ullah Khan ${ }^{1}$ \\ ${ }^{1}$ International Islamic University Islamabad, Pakistan
}

\begin{abstract}
The purpose of this paper was to investigate those factors which influence accounting students in selecting their career paths alongside graduation. In the current study, non-probability purposive sampling was used, in order to collect data, there are two sources namely primary and secondary we used, primary source to distribute questionnaire. The questionnaire was distributed among 530 male and female students that are enrolled in universities in different provinces as well as from capital city of the country also included at Pakistan, 470 filled questionnaires were collected while 67 were found incomplete/unusable mean not to specify gender, age, etc. and so were excluded from the analyses, therefore, 470 were used for analysis. A response rate of $89 \%$ approximately was achieved.

In the findings of this paper we include two new variables in the model to examine which factors are significantly influencing accounting students preferences towards their career paths. The two new variables source of information from media and recruitment and selection are taken, both have positive relation with career path. This paper is the first study undertaken in Pakistan to successfully provide a new dimension to accounting students in choosing their career paths upon graduation.
\end{abstract}

\section{Introduction}

In August 1992 The Institute of Certified Public Accountants of Pakistan (ICPAP) was established as an association with the goal to contribute world class preparing in Management, Finance, Auditing, Corporate and Tax Laws and Accounting to students working officials and experts in Pakistan. The Institute of Certified Public Accountants of Pakistan (ICPAP) aims to drive the Certified Public Accountant (CPA) program with a best in class course plan and educational modules. Consistently, the Certified Public Accountant (CPA) program got solid response from a wide cross region of understudies, capable and working authorities, starting at now there are 1700 CPAs who viably completed the CPA Program of ICPAP and got the CPA Charter. Today the ICPAP is the principle voice of corporate accountants and money related officials. Individuals comprise of experts, for example, CFOs, CEOs, budgetary controllers and others in the field of corporate accounting and money related administration. (Hutaibat, 2012) clarified that the absence of inclination for administration accounting could be because of the absence of formal instruction in administration accounting. The Past writing uncovered that other impacting component utilizing the social psychological profession hypothesis incorporate characteristic moti-

\footnotetext{
${ }^{1}$ Corresponding author.

Email: rizwanhayat1989@gmail.com
}

http:/ / www.jbrc.pk

vation, extrinsic motivation, outsiders impact and career introduction.

Organization of Chartered Accountants of Pakistan (ICAP) is an expert accounting body in Pakistan. Starting at July 2016, it had 8,819 individuals working in and outside Pakistan. On 1 July 1961 the establishment was set up to coordinate the calling of accounting in Pakistan. It is a legal free body set up under the Chartered Accountants Ordinance 1961. With the vast improvement in the calling, the CA Ordinance and Bye-Laws were reconsidered in 1983. The course of ICAP includes a mix of hypothetical instruction and handy preparation which run instantaneously for a time of 3.5 years and gives an understudy with information, capacity, abilities and different qualities required of an expert accountant.

Vysotskaya et al. (2016) utilized an explanatory path to deal with show that accounting can be spoken to as an arrangement of conditions comprehended through fundamental framework polynomial math capacities. They recommended that such a portrayal of the accounting framework might be useful in widening students' understanding and conceptualization of accounting as a numerical framework. There are some reasons in accounting programs, battle to enlist students and therefore the reasons go from impression of the extent of bother to price, dread of mathemat- 
ics, or perhaps absence of topic learning (Schneider and Sheikh, 2012). In any case, the availability of accounting specialists stays level, however the interest for accountants, particularly bonded open accountants (CPAs), keeps on increasing (Briggs and He, 2012).

New body changes to expand examination with the Enron Bankruptcy in 2002 and therefore the financial emergency in 2008 have created wild requests (Akers et al., 2014). The increasing range of resigning accounting personnel and therefore the inadequate range of accounting specialist popping into sympathy toward specialists and profound organizations (Devi et al., 2012). These worries square measure one thought mimicking the career paths being picked by the deficient range of accounting graduates, because the interest for accounting students increment, the amount of enrolees has confronted a downhill pattern, that prompts associate far more than work for the people who decide the knowledgeable course of accounting (Suddaby et al., 2015). The amount of accounting graduates with a specialization in examining, assembling, cost, and alternative business territories is two hundredth additional noteworthy in distinction with totally different business degrees (Plumlee and Reckers, 2014).

Around $25 \%$ of accounting students come up short in view of disgraceful direction, and half change their specialization, which leaves roughly $25 \%$ of the underlying populace of students selected in an accounting project to be accessible as future representatives (Suddaby et al., 2015). Little has been done to address the difficulties going up against the accounting scholarly group and in addition the accounting profession all in all (HassabElnaby et al., 2012). Declining recruitment in accounting programs (Hopper, 2013), expanded weakening among accounting educators (Davis and Jones, 2014), and accounting understudy motivation sorts (Hopper, 2013), all have been already inspected without giving determination of the issue of the absence of accounting staff to address the necessities of organizations. Also, there is a shortage of exact research on the status and patterns of accounting educational modules, recruitment, and conveyance of learning substance (Apostolou et al., 2013). Unless there is powerful data on the clear qualities of college projects on accounting, the projects that report problems on accounting are set to be guaranteed toward disappointment (Apostolou et al., 2013).

The goal of this review is to distinguish components which impact accounting students in picking their profession paths upon graduation, experimental review from Pakistan. Essentially, accounting students have numerous options as far as professional success upon their graduation is concerned. For example, they may progress into zones of budgetary accounting, tax assessment, administration accounting, reviewing, fund, and so on. This review incorporates add up to five factors in which one profession path is needy vari- able and four free factor, though, two taken from past review, in particular intrinsic motivation, career presentation and staying two new factors representative prerequisite and wellspring of data from media in the model to figure out which components are huge and affecting accounting students' inclination towards their career paths. Other than that, instructive organizations may profit by this review as subject educators or scholarly instructors may utilize the discoveries of this review to help students in their profession decisions. On top of that, expert accounting bodies may likewise profit as the discoveries could give a premise to them to outline their part recruitment techniques.

\section{Literature Review}

\subsection{Social Cognitive Career Theory}

Social Cognitive Career Theory (SCCT) by Lent et al. (1994) clarifies the communication among individual, logical, and behavioral factors in the process, in which professional interests and career decisions create, and an individual holds on in her or his career. A few reviews have analyzed the center socio-intellectual factors of the model and have discovered solid support for suggestions identified with these factors (Ali et al., 2005; Lent et al., 2003, 2005). The present review tests a few SCCT suggestions by exploring diverse schools and Universities students' profession decisions crosswise over Pakistan (2017) topics and reaches out past reviews by including individual and logical factors in the SCCT show and looking at the model fit crosswise over sexual orientation gatherings and college setting.

A couple of years after the fact, some experimental research upheld this interrelation that with higher self-adequacy, there is a change of result desires (Fouad and Smith, 1996; Lent et al., 2008). An audit of accounting training writing by Watson et al. (2007) incorporates an examination of learning styles and innovation (Tho, 1994). For instance, McDuffie and Smith (2006) address the specific utilization of a review announcing framework as a showing help and its effect on students' execution. Schleifer and Dull (2009) consider metacognition as a critical part of self-managed learning and in this manner having potential as a learning aptitude or credit that can serve to enhance accounting instruction and execution. Fox and McDonald (2010) consider the effect of an understudy peer-coaching program on first year students' scholastic execution, while Jones and Wright (2010) broaden past work by joining the impact of intellectual style and the utilization or nonutilization of two adaptations of a hypertext learning help and their connection on understudy execution in Advanced Financial Accounting.

As clarified by Chantara et al. (2011), SCCT includes three essential perspectives, in particular: self- 
adequacy, result desires and objectives. Self-efficacy alludes to a particulars confidence about his or her abilities to perform a strategy, which is identified with profession accomplishment (Ng et al., 2017). People with solid feeling of self-efficacy will for the most part place extraordinary exertion in finishing assignments, in spite of the troubles they experience. Result desires, then again, allude to the convictions on the future outcome after a specific conduct is performed (Chantara et al., 2011; $\mathrm{Ng}$ et al., 2017). In conclusion, objectives are characterized as a man's assurance to choose particular results of learning or execution. The organization of objectives speaks to a basic system, which includes the strategy which a man exercise his or her selfstrengthening.

\subsection{Career Path}

A career path is the unfaltering advancement an individual makes in his or her profession. A man's profession path may include one employment or a progression of jobs. The accounting profession has seen critical and huge moves in the course of the most recent years, for example, testing moral quandaries, emotional results for those occupied with false revealing, expanded directions, and changes in announcing principles. These elements can have an impact on those turning into an accounting major and also the elements that influence their decision of different jobs in the field. The argument behind this that graduates of accounting picked their path of profession by implication, jeopardizes the manageability in the field of accounting as a study of the program (Urbano et al., 2015). In light of an investigation of accounting assistants, Tong et al. (2008) found that individual job fit influences accounting students' career choices (considerably more than impression of individual association fit). Comparable research using the idea of fit has been done in advertising instruction in light of an expressed need to enhance the enrolling procedure for deals students (Agnihotri et al., 2014). Like earlier work, their outcomes showed that accounting students/experts tend to display detecting and judging qualities, recommending they focus on data getting through their faculties (as opposed to searching for examples) and like having things chosen instead of remaining open to new data (Swain and Olsen, 2011).

The influence and freedom of the accounting profession means that the viable authorization of accounting models (Ball et al., 2003). As per Joseph et al. (2012), an individuals career path could likewise be affected by the individual characteristics of the people. The ICAP resolved to manage the instruction, preparing and examination of its students keeping in mind the end goal to guarantee that a recently qualified Chartered Accountant can keep on being certainly. Being prepared to attempt work, requesting qualities and abilities ex- pected of a contracted accountant and being capable, with appropriate acceptance, rapidly to get any extra accounting aptitudes required for specific errand in broad daylight hone, industry, trade or somewhere else.

From 1994 a Pre-entry Proficiency Test (PPT) was acquainted to decide the reasonableness of hopefuls before being enlisted as Trainee Students/Full Time Students. PPT was required for all contestants with the exception of the individuals who were absolved from PPT however later when new arrangement was presented in 2014; it was totally barred from the course.

There appear to be numerous hypotheses with reference to why the discoveries of Madsen (2014) study were blended, however one steady contrast amongst accounting and different business projects is the compensation received by accounting graduates has stayed solid in respect to the compensation received by different business degrees, which stays static (Swanson and Creed, 2014). The earnest mindfulness was fundamentally more in the accounting field basic component for those who are non-accountant, high limit of understudies than prudent job prospects and high netting idle (Pan and Perera, 2012). Students' whittling down fall in programs of accountings was one of the difficulties in taking care of the yearly want of graduates in the accounting (Kruglanski et al., 2012). Thus, researchers retained endeavors to discover approaches to handle this test (Byrne et al., 2012). With a specific end goal to see how students can be held, a few variables identified with maintenance should be examined. Hindrances that may impact maintenance of understudies accounting incorporate motivation (Apostolou et al., 2013; Bagley et al., 2012; Byrne et al., 2012; Curtis, 2011; Jairam and Kahl Jr, 2012; Pan and Perera, 2012; Upton and Arrington, 2011) identified attributes by Curtis (2011), scholarly setting given by the school (Byrne et al., 2012; Curtis, 2011; Danino et al., 2013), and social components (Byrne et al., 2012; Danino et al., 2013). Each of these maintenance variables are talked about with regards to accounting graduates career path decisions.

\subsection{Intrinsic Motivation}

Students for the maximum part observe two remarkable types of motivation: intrinsic and extrinsic (Bagley et al., 2012). Intrinsic motivation is desire to prepare or accomplish to some degree since one exactly requires and takes feeling or stems motivation from undertaking it (Byrne et al., 2012). Intrinsic motivation is most ordinarily described as "helping out its own particular sake,". All the more as of late, Marriott and Marriott (2003) found that as students advance through their degrees, real enthusiasm for account diminishes. Tan and Laswad (2006) additionally found that students deciding for an accounting ma- 
jor were impacted by their enthusiasm for accounting and were sure about contemplating accounting. Conversely, non-accounting majors saw accounting as an exhausting scholarly major. Depicted as a natural process which individuals perform for interior reasons or for their own look of nervousness, intrinsic motivation is more predominant in accounting graduates looking for a profession path in the scholarly world (Davis and Jones, 2014).

Past reviews have additionally highlighted the connector between level of premium and the nature of learnedness and scholarship results of college students (Entwistle and Waterston, 1988; Ramsden, 2003). Given these association, students intrinsically inspired by contemplating accountancy would probably draw in with the substance in a way of life that mirrors the furtherance of building complex levels of comprehension of accounting ideas (Mladenovic, 2000). Discoveries found that intrinsic motive can emphatically influence students' career paths. Scholarly person inclines toward accounting essentially in light of the fact that accounting is intriguing. The students are likewise sure about getting great outcomes and are dependent on numbers and figures. These variables had intrinsically propelled students to study accounting. The intrigue/pleasure scale is considered as a self-report measure of characteristic motivation and the main scale that evaluates intrinsic motivation (Self-assurance hypothesis, 2016). Intrinsic motivation includes the inclination to seek after a scholastic errand in light of activity, be psychologically occupied with the undertaking by centring consideration, and endeavour to comprehend the subject by taking part in critical learning (Jairam and Kahl Jr, 2012).

An individual must have an intrinsic motivation to take in all the vital aptitudes expected to play out an undertaking to wind up plainly skilled and accordingly, intrinsically roused people can support understudy learning and accomplishment superior to outwardly propelled people (Jairam and Kahl Jr, 2012). Another past review directed by $\mathrm{Ng}$ et al. (2017) indicated sentiments and discernment towards the accounting profession have positive and huge impact towards career choice in accounting students. Then again, as per Adeleke et al. (2013), identified variables which included bent and mentality are appeared as huge elements of identity in the advance of profession intrigue. Subsequently, this prompts the theory that:

$H_{1}$ : There is a positive relationship between intrinsic motivation and career path.

\subsection{Career Exposure}

There is by all accounts general agreement in the writing that earlier introduction assumes an essential part in modelling goals (Zapkau et al., 2017, 2015). Tak- ing after (Krueger, 1993) four sorts of such presentation are ordinarily analyzed: (a) past encounters (b) family introduction; (c) close contacts with individuals (companions and relatives) occupied with accounting studies; and (d) related involvements in work in little or youthful firm. Most generally inquired about are the initial two sorts of presentation and since they are most applicable to our examination we might introduce the key discoveries beneath.

This exploration generally depends on quantitative examination in view of extensive date sets like Flash Eurobarometer Survey on accounting investigations of the University Spirit Students' Survey. Relatives, especially guardians move toward becoming good examples for the more youthful era furnishing them with motivation, learning, motivation, help to give the more youthful era a chance to characterize their self-idea (Gibson, 2004), additionally support and direction (Nauta and Kokaly, 2001).

Nonetheless, solid parental desires may now and again prompt clashing circumstances and settling on profession choices by students troublesome (Leung et al., 2011; Murphy and Lambrechts, 2015). On a basic level, the family condition impacts all career choices - work, autonomous expert action open administration, scholastic profession or the entrepreneurial course (Whiston and Keller, 2004). Nonetheless, in the last case the effect is especially solid and multidirectional (De Wit and Van Winden, 1989; Tognazzo et al., 2016). Coordinate presentation in the guardians' accounting studies is a proficient method for increasing important hands on experience which is not typically accessible for those not being conceived in families (Parker and Van Praag, 2012).

In this review, career introduction alludes to students' presentation to profession related data. As indicated by Ghani et al. (2009), most accounting students pick up career presentation through expert accounting bodies. Ghani et al. (2009) remarked that it is critical for students to be presented to the path of an accountant's job and what sort of profession it offers. With more prominent presentation on profession related data, one can settle on better choice in their career decision. Various reviews in the accounting training, writing, it was found that the majority of students acquired their profession introduction amid their review in the colleges via their scholastics by Miller and Wager (1971) and Erkut and Mokros (1984). Further gathering of studies proposed that students frequently picked up the information about the accounting profession from their families, companions and selection representatives (DeZoort et al., 1997).

$\mathrm{H}_{2}$ : There is a positive relationship between career exposure and career path. 


\subsection{Source of Information from Media}

Today's growing example of using new correspondence progressions has extended the potential results for how people can send and get information. With not a lot of points of confinement on the kind of prospecting that might be endeavored, online systems administration examination is as often as possibly associated with examples in 'gigantic data'. There is no obvious purpose of repression to the amount of messages that might be gotten or the estimations of society that might be investigated: "we no longer need to pick between data size and data significance. We can think revise bearings molded by, billions of social expressions, experiences, messages, and associations" (Manovich, 2011) (pp. 462-463). There are elite prerequisites about what this kind of research may draw in specialists to do (Goldin, 2010), however without creative work practices expected to set the foundations by finding what is open in the message, working with the industrious surges of trades is presumably going to stay testing and outside the compass of generally analysts. Information searching that it is the media which is such one development which seems extended use as it is one of the sources of information (Pepitone, 2010). For Instance, web based systems administration are being used to search for information about honest to goodness focuses that might be capable life and also singular life related, for instance, surrendering and hovering to-the minute information (Sutter, 2010). As this Seat Report prescribes "Society of people use online social instruments to assemble information, share stories, and look at concerns" Fox, (2011, p. 5).

Khan et al. (2016) detailed the consequences of an online study finished by students enlisted in a firstyear accounting course at four Australian colleges with respect to their utilization of media for scholarly purposes. Facebook was the essential online networking outlet utilized by the students. Overall, students revealed investing as much energy in media every week as they spent on learning exercises. An extensive bit of the students showed that they utilized media for scholarly purposes, in spite of the fact that document sharing (e.g., notes, past exam inquiries, and answers to practice exams) was the essential scholastic reason recognized. A few students revealed utilizing online networking for finishing assignments or ventures with colleagues. The creators found a noteworthy connection between GPA (self-announced by the students) and the utilization of online networking for scholastic purposes.

The sorts of data proposed in the chief section of this paper share no short of what one thing in like path: they all take course of action with uncertain conditions highlighted by potential hazard. As a rule, when helplessness addresses danger, folks successfully participate in information gathering pursuing (Brashers et al., 2000; Spence et al., 2006). In any case, nearby standard sorts of media, more present by source of media dynamically available for information pursuing. One sort of channel that gives various chances to this explanation behind existing is the Web. Investigation alludes that public use the Web in search for information about crises (Spence et al., 2006). All the more starting late, internet organizing has given another and possibly viable stage for people to use in search for such information.

$\mathrm{H}_{3}$ : There is a positive relationship between source of information from media and career path.

\subsection{Recruitment and Selection}

Each one of the frameworks and paths which are used as a piece of system of recruitment are when in doubt in a general sense surveyed in this exploration. For the determination of the representatives, every affiliation uses particular paths and frameworks for decision. Each one of the theories, techniques and strategies which are used as a piece of method of enrolment, will be analysed in a general sense, for the accomplishment of an affiliation, now both inside and outside frameworks are being used by the relationship in the selection methodology. Without a doubt, a diligent test confronting the accounting profession keeps on being the recruitment of top notch representatives who are a solid match for jobs in the accounting field (Dalton et al., 2013).

Newman and Lyon (2009) pointed the ordinary necessities for making huge pool for determination of the representatives is Job Analysis. For recruitment handle get ready work examination is the underlying stride. As demonstrated by Dalton et al. (2013) giving promotions for purge jobs is a standard methodology to find the right pool of hopefuls. Davidson et al. (2007) discussed the challenges that effect the contracting in associations, it was an examination facilitated by Equa Terra and studied more than 150 open portion specialists from United States to focus their business sharpens. Kaplan et al. (2004) recognized a couple of issues that incite terrible work decisions; most of them were deadness in masterminding, achieving poor determination of representatives in light of poor business examination. Nyangaresi et al. (2013) stressed on the point that in this forceful world, affiliations need to pick capable and adept individuals remembering the true objective to make and create as an affiliation. Khan et al. (2011) examined open division of Bangladesh and recognized HR at workplaces is feeble especially the branch of recruitment and determination. The HR division does not do suitable job examination, which prompts poor expected arrangement of duties and in this path the issue of getting the right plausibility for the work as authentic job examination is not done in 
that capacity prompts issue of recruitment and choice in the all-inclusive community part affiliations. Khan et al. (2011) asked about how HR sharpens out in the open territory of Pakistan, which is amazingly extraordinary. He recognized the importance of HR practices and choosing the ideal individual for the work. The investigation shed light on exact job examination for picking the right probability for the right business, which was completely neglected out in the open region of Pakistan as showed by his revelations. He, moreover said that choice of the representatives should be done according to the necessity of the job.

$\mathrm{H}_{4}$ : There is a positive relationship between employees recruitment and selection with career path.

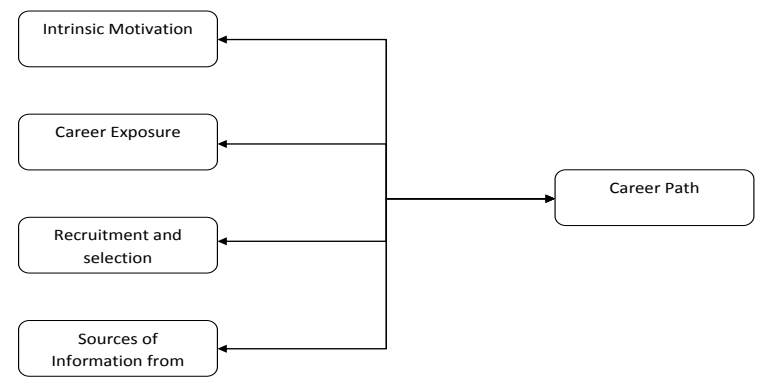

Figure 1: Framework

\section{Methodology}

\subsection{Sample and Procedure}

In the current study, non-probability purposive sampling was used. We used primary source to collect data through survey method. The questionnaire was distributed among 530 male and female students that are enrolled in universities in different provinces as well as from capital city of the country. 470 filled questionnaires were collected while 67 were found incomplete/unusable. A response rate of $89 \%$ approximately was achieved. Before submitting the survey, the entire particular were fully elaborated to the respondents in preliminary procedure to create convenience in filling the questionnaires and achieve relevant data. The respondents demographic are given in the following table according their response percentage. The respondents consist of $223(47.4 \%)$ females and $247(52.6 \%)$ males. Most of the respondents are around 19-21 years old, 22-24 years old, and above 25 years old at $34.3 \%, 32.8 \%$ and $33.0 \%$ respectively. There are 105 respondents $(22.3 \%)$ in the first year of the degree programme, respondents in the second year are $128(27.2 \%)$ and third year number at $118(25.1 \%)$ and lastly in the fourth year students respondent are 119 $(25.3 \%)$. More than half of the respondents do not have family or friends who are accountants. Close to half of the respondents have indicated that the accounting programme was their first choice.

\subsection{Instruments}

Intrinsic Motivation was measured using five construct from Odia and Ogiedu (2013), Career exposure measured from Hutaibat (2012), Career Path from Yusuf (2011) both have five items, Source of Information from Media (TV, Radio, Magazine, Newspaper, Internet) and Recruitment and selection from Kolvereid (1996). Each item used a five-point Likert scale, ranging from strongly disagrees, disagree, neutral, agree, to strongly agree. Cronbachs alpha value of the questionnaire was 0.76 , which satisfies the minimum criteria of 0.60 Hair et al. (1998). Thus, our construct measures are considered to be reliable and we can proceed with further analysis.

\section{Results}

The current study used Reliability, descriptive statistics, and regression tests in order to analyze the data. The present study uses structural equation modelling (SEM) that allows for the simultaneous estimation and testing of the relationships of pursuit. In SEM causal processes are represented by a series of structural equations that can be mannequin graphically to aid in conceptualizing a theoretical model. For the design of this study, pupil was asked to identify their age, gender, and the level of study mean first,second,third and fourth year of the accounting studies.Evidence from the questionnaire survey can then be used mainly for description, explanation or hypothesis testing.

\subsection{Correlation Matrix}

The main objective of the study is to analyze the effect of various factors on Career Path decision making. Several tests have been applied; summary of the results is given in Table 4.1 reports means, standard deviations, and Pearson correlations among studied variables. Hierarchical regression modeling (HRM) was employed to test our hypotheses.

Table 4.1 presents descriptive statistics and correlations among the variables. The variable have a significant positive relationship when $(\mathrm{P}<0.05)$ and negative correlation between variables when the $(\mathrm{P}>0.05)$.In addition, the reliability test was also analysed in which the Cronbach alphas are $(0.733,0.601$, and 0.640$)$ for each variable in the Table 4.1.

Table 4.1 shows the results of correlation matrix. As per the findings, Career path is positively and significantly correlated with intrinsic motivation $\left(0.1859^{*}\right)$, 
Table 4.1: Means, Standard Deviation, coefficient of Correlation and Reliability

\begin{tabular}{|c|c|c|c|c|c|c|c|}
\hline & & & 1 & 2 & 3 & 4 & 5 \\
\hline Variables & Mean & St.D & & & & & \\
\hline Career Path & 2.6856 & .97284 & - & & & & \\
\hline Intrinsic Motivation & 3.7127 & .55496 & $0.185^{*}$ & $(0.733)$ & & & \\
\hline Career Exposure & 3.7841 & 44548 & $0.005 \mathrm{~ns}$ & $0.277^{*}$ & $(0.601)$ & & \\
\hline Recruitment \& Selection & 3.5480 & 64050 & $0.143^{*}$ & $0.535^{*}$ & $0.351^{*}$ & $(0.64)$ & \\
\hline Source of Information from Media & 3.488 & .88235 & $0.201^{*}$ & $0.321^{*}$ & $0.284^{*}$ & $0.145^{*}$ & $(0.712)$ \\
\hline
\end{tabular}

$n=470$, alpha reliabilities are presented in parentheses. ${ }^{*} P_{j} 0.05, n s=$ not significance

Table 4.2: Linear Regression

\begin{tabular}{lccc}
\hline \multicolumn{4}{c}{ Career Path } \\
\hline Model & Unstandardized Coefficients B & $\mathbf{t}$ & Sig. \\
\hline (Constant) & 3.103 & 18.866 & $.000^{* *}$ \\
Gender & .022 & .446 & .656 \\
Age & .391 & 2.648 & $.009^{*}$ \\
Intrinsic Motivation & .141 & 3.532 & $.027^{*}$ \\
Career Exposure & .209 & 4.144 & $.000^{* *}$ \\
Recruitment \& Selection & .279 & 2.811 & $.052^{*}$ \\
Source of Information from Media & .347 & 2.576 & $.003^{*}$ \\
R Square & .036 & & \\
Change R Square & .218 & & \\
\hline
\end{tabular}

a. Dependent Variable: career path

$P$ value $<.05$ significant

recruitment and selection $\left(0.143^{*}\right)$ and Source of information from media $\left(0.201^{*}\right)$. Whereas, the correlation between career path and career exposure is non significant. Similarly, instrinsic motivation positively correlated with career exposure at $0.277^{*}$, as well as with recruitment and selection and source of information at $0.535^{*}$ and $0.321^{*}$, respectively. Table also shows the reliability of each variable, which is well within acceptable range.

\subsection{Regression Analysis}

The first hypothesis of this study states that there is a positive relationship between intrinsic motivation and career path. So based on the result presented in the Table 4.2, we found a significant positive impact between intrinsic motivation and career path $(\mathrm{r}=0.535, \mathrm{p}=$ $0.000)$. The second hypothesis stated that there is significant positive correlation between career exposure and career path. ( $\mathrm{r}=0.351, \mathrm{p}=0.000)$. the third hypothesis of this study proposed that There is a positive relationship between source of information from media and career path so according to presented result in Table 4.1 that there is direct positive significant correlation between recruitment and career path $(\mathrm{r}=0.143, \mathrm{p}=0.020)$.

The first hypothesis of our study was that there is a positive relationship between intrinsic motivation and career path. So according to the results presented in Table 4.2 that overconfidence has a significant positive impact on intrinsic motivation and career path $\beta=0.141$ and $\mathrm{P}<0.05)$. So, intrinsic motivation has strong and significant relation with career path (Jairam and Kahl Jr, 2012; Ng et al., 2017). According to previous studies we suggest that there are strong positive relation. Similarly, where $\beta=.209$ and $\mathrm{p}<.05$, due to these results we suggested that career exposure has green signal for connection with career path,leading to acceptance of hypothesis two as well (Parker and Van Praag, 2012; Tognazzo et al., 2016). Hypothesis three suggests that there is a positive relationship between employees recruitment and selection and career path so according to the result presented in the Table $4.2, \beta=.279$ and $\mathrm{p}$ $<.05, \mathrm{H}_{3}$ has been accepted. As per hypothesis four, there is a positive relationship between source of information from media with career path; the regression results indicate that $\beta=.347$ and $\mathrm{p}<.05$, lending support to the hypothesis four as well (Khan et al., 2016). Similarly, the change in $\mathrm{R}$ square (.218) indicates that $22 \%$ variation dependent variable is caused by independent variables, further substantiating the results.

Ultimately, based on the study results and lending support from the previous studies as well, we conclude that in current study, independent variables have a positive relation with their dependent variable. 


\section{Conclusion and Discussion}

This review is valuable to the expert accounting bodies in planning their methodologies for individuals' recruitment. Be that as it may, the consequences of this review might be constrained in two paths. To start with, this review was led on a solitary private organization in Pakistan. Second, the information was gathered utilizing comfort examining strategy. The outcomes, consequently, can't be summed up to all accounting students in Pakistan. In any case, the discoveries of this review may at present be valuable to the expert accounting bodies as the private college picked initiates an enormous number of accounting students in Pakistan every year for its accounting program. From the discoveries of this review, a lack of qualified cost bookkeepers as specified before could be illuminated by making enthusiasm for auxiliary school students before they go into tertiary training. Proficient bodies, for example, Certified Public Accountant (CPA) and ACCA may consider giving more talks, courses and occasions to enhance auxiliary school students enthusiasm towards administration accounting. Furthermore, talks, courses and occasions on the administration accounting profession could likewise be given to tertiary students to open them to career paths in the administration accounting zone. With more career introduction towards the administration accounting career, accounting students enthusiasm towards administration accounting career could be additionally made strides. The after effects of this review could be further enhanced. To control variables, for example, year of program or/and age, could be incorporated to further improve the model. It might likewise be intriguing for future research to extend its degree to look at different business students who chose not to major in accounting.

\section{References}

Adeleke, M. S., Binuomote, M. O., and Adeyinka, M. (2013). Determinants of students academic performance in financial accounting among senior secondary school leavers in oyo state. International Journal of Business and Management Invention, 2(5):48-59.

Agnihotri, R., Bonney, L., Dixon, A. L., Erffmeyer, R., Pullins, E. B., Sojka, J. Z., and West, V. (2014). Developing a stakeholder approach for recruiting top-level sales students. Journal of Marketing Education, 36(1):75-86.

Akers, M. D., Giacomino, D., Courtney, K., and Johnson, O. (2014). A profile of top performers on the uniform cpa exam.

Ali, S. R., McWhirter, E. H., and Chronister, K. M. (2005). Selfefficacy and vocational outcome expectations for adoles- cents of lower socioeconomic status: A pilot study. Journal of career assessment, 13(1):40-58.

Apostolou, B., Dorminey, J. W., Hassell, J. M., and Watson, S. F. (2013). Accounting education literature review (20102012). Journal of Accounting Education, 31(2):107-161.

Bagley, P. L., Dalton, D., and Ortegren, M. (2012). The factors that affect accountants' decisions to seek careers with big 4 versus non-big 4 accounting firms. Accounting Horizons, 26(2):239-264.

Ball, R., Robin, A., and Wu, J. S. (2003). Incentives versus standards: properties of accounting income in four east asian countries. Journal of accounting and economics, 36(1-3):235270 .

Brashers, D. E., Neidig, J. L., Haas, S. M., Dobbs, L. K., Cardillo, L. W., and Russell, J. A. (2000). Communication in the management of uncertainty: The case of persons living with hiv or aids. Communications Monographs, 67(1):63-84.

Briggs, G. P. and He, L. (2012). The 150 credit-hour requirement and cpa examination pass ratesa four year study. Accounting Education, 21(1):97-108.

Byrne, M., Flood, B., Hassall, T., Joyce, J., Montaño, J. L. A., González, J. M. G., and Tourna-Germanou, E. (2012). Motivations, expectations and preparedness for higher education: A study of accounting students in ireland, the uk, spain and greece. In Accounting Forum, volume 36, pages 134-144. Elsevier.

Chantara, S., Kaewkuekool, S., and Koul, R. (2011). Selfdetermination theory and career aspirations: A review of literature. institutions, 7:9.

Curtis, S. M. (2011). Formative assessment in accounting education and some initial evidence on its use for instructional sequencing. Journal of Accounting Education, 29(4):191-211.

Dalton, D. W., Buchheit, S., and McMillan, J. J. (2013). Audit and tax career paths in public accounting: An analysis of student and professional perceptions. Accounting Horizons, 28(2):213-231.

Danino, N., May, L., and Mitchell, N. (2013). Reprogramming 1st year students: An action research case study. UCLan Journal of Pedagogic Research, 4.

Davidson, G., Lepeak, S., and Newman, E. (2007). The impact of the aging workforce on public sector organizations and mission. International Public Management Association for Human Resources.

Davis, H. E. and Jones, K. (2014). The impact of changes in accounting program retention policies. AND ACCOUNTING, page 31 .

De Wit, G. and Van Winden, F. A. (1989). An empirical analysis of self-employment in the netherlands. Small Business Economics, 1(4):263-272.

Devi, S. S., Kumar, R., and Raju, S. K. (2012). Partnering with practice for accounting education: Evidence from the pacific. 
DeZoort, F. T., Lord, A. T., and Cargile, B. R. (1997). A comparison of accounting professors' and students' perceptions of the public accounting work environment. Issues in Accounting Education, 12(2):281.

Entwistle, N. and Waterston, S. (1988). Approaches to studying and levels of processing in university students. British Journal of Educational Psychology, 58(3):258-265.

Erkut, S. and Mokros, J. R. (1984). Professors as models and mentors for college students. American Educational Research Journal, 21(2):399-417.

Fouad, N. A. and Smith, P. L. (1996). A test of a social cognitive model for middle school students: Math and science. Journal of Counseling Psychology, 43(3):338.

Fox, S. C. and McDonald, A. G. (2010). Chemical and thermal characterization of three industrial lignins and their corresponding lignin esters. BioResources, 5(2):990-1009.

Ghani, E. K., Said, J., Nasir, N. M., and Jusoff, K. (2009). The 21st century accounting career from the perspective of the malaysian university students. Asian Social Science, 4(8):73.

Gibson, D. E. (2004). Role models in career development: $\mathrm{New}$ directions for theory and research. Journal of Vocational Behavior, 65(1):134-156.

Goldin, I. (2010). World wide research: Reshaping the sciences and humanities. MIT Press.

Hair, J. F., Anderson, R. E., Tatham, R. L., and Black, W. C. (1998). Multivariate data analysis. 1998. Upper Saddle River.

HassabElnaby, H. R., Dobrzykowski, D. D., and Tran, O. T. (2012). Applying the international medical graduate program model to alleviate the supply shortage of accounting doctoral faculty. Decision Sciences Journal of Innovative Education, 10(2):271-294.

Hopper, T. (2013). Making accounting degrees fit for a university. Critical Perspectives on Accounting, 24(2):127-135.

Hutaibat, K. A. (2012). Interest in the management accounting profession: accounting students perceptions in jordanian universities. Asian Social Science, 8(3):303.

Jairam, D. and Kahl Jr, D. H. (2012). Navigating the doctoral experience: The role of social support in successful degree completion. International Journal of Doctoral Studies, 7:311329.

Jones, S. H. and Wright, M. E. (2010). The effects of a hypertext learning aid and cognitive style on performance in advanced financial accounting. Issues in Accounting Education, 25(1):35-58.

Joseph, D., Boh, W. F., Ang, S., and Slaughter, S. A. (2012). The career paths less (or more) traveled: A sequence analysis of it career histories, mobility patterns, and career success. MIS Quarterly, pages 427-452.

Kaplan, R. S., Kaplan, R. E., Norton, D. P., Norton, D. P., Davenport, T. H., et al. (2004). Strategy maps: Converting intangible assets into tangible outcomes. Harvard Business Press.
Khan, T., Kend, M., and Robertson, S. (2016). Use of social media by university accounting students and its impact on learning outcomes. Accounting Education, 25(6):534-567.

Khan, W., Ahmed, A. A. A., and Neogy, K. (2011). Recruitment, selection issues and challenges in public sector: Bangladesh case study.

Kolvereid, L. (1996). Prediction of employment status choice intentions. Entrepreneurship Theory and practice, 21(1):47-58.

Krueger, N. (1993). The impact of prior entrepreneurial exposure on perceptions of new venture feasibility and desirability. Entrepreneurship theory and practice, 18(1):5-21.

Kruglanski, A. W., Bélanger, J. J., Chen, X., Köpetz, C., Pierro, A., and Mannetti, L. (2012). The energetics of motivated cognition: a force-field analysis. Psychological review, 119(1):1.

Lent, R. W., Brown, S. D., and Hackett, G. (1994). Toward a unifying social cognitive theory of career and academic interest, choice, and performance. Journal of vocational behavior, 45(1):79-122.

Lent, R. W., Brown, S. D., Nota, L., and Soresi, S. (2003). Testing social cognitive interest and choice hypotheses across holland types in italian high school students. Journal of Vocational Behavior, 62(1):101-118.

Lent, R. W., Brown, S. D., Sheu, H.-B., Schmidt, J., Brenner, B. R., Gloster, C. S., Wilkins, G., Schmidt, L. C., Lyons, H., and Treistman, D. (2005). Social cognitive predictors of academic interests and goals in engineering: Utility for women and students at historically black universities. Journal of Counseling Psychology, 52(1):84.

Lent, R. W., Sheu, H.-B., Singley, D., Schmidt, J. A., Schmidt, L. C., and Gloster, C. S. (2008). Longitudinal relations of self-efficacy to outcome expectations, interests, and major choice goals in engineering students. Journal of Vocational Behavior, 73(2):328-335.

Leung, S. A., Hou, Z.-J., Gati, I., and Li, X. (2011). Effects of parental expectations and cultural-values orientation on career decision-making difficulties of chinese university students. Journal of Vocational Behavior, 78(1):11-20.

Madsen, P. E. (2014). Has the quality of accounting education declined? The Accounting Review, 90(3):1115-1147.

Manovich, L. (2011). Trending: The promises and the challenges of big social data. Debates in the digital humanities, 2:460-475.

Marriott, P. and Marriott, N. (2003). Are we turning them on? a longitudinal study of undergraduate accounting students' attitudes towards accounting as a profession. Accounting education, 12(2):113-133.

McDuffie, R. S. and Smith, L. M. (2006). Impact of an audit reporting expert system on learning performance: a teaching note. Accounting Education: an international journal, 15(01):89-102. 
Miller, G. A. and Wager, L. W. (1971). Adult socialization, organizational structure, and role orientations. Administrative Science Quarterly, pages 151-163.

Mladenovic, R. (2000). An investigation into ways of challenging introductory accounting students' negative perceptions of accounting. Accounting Education, 9(2):135-155.

Murphy, L. and Lambrechts, F. (2015). Investigating the actual career decisions of the next generation: The impact of family business involvement. Journal of Family Business Strategy, 6(1):33-44.

Nauta, M. M. and Kokaly, M. L. (2001). Assessing role model influences on students' academic and vocational decisions. Journal of Career Assessment, 9(1):81-99.

Newman, D. A. and Lyon, J. S. (2009). Recruitment efforts to reduce adverse impact: Targeted recruiting for personality, cognitive ability, and diversity. Journal of Applied Psychology, 94(2):298.

Ng, Y.-H., Lai, S.-P., Su, Z.-P., Yap, J.-Y., Teoh, H.-Q., and Lee, H. (2017). Factors influencing accounting students career paths. Journal of Management Development, 36(3):319-329.

Nyangaresi, M., Nejeru, W., Mutavi, T., and Waithaka, N. (2013). Recruitment and selection process: A case of city council of nairobi, kenya. Review of Contemporary Business Research, 2.

Odia, J. and Ogiedu, K. (2013). Factors affecting the study of accounting in nigerian universities. Journal of Educational and Social Research, 3(3):89.

Pan, P. and Perera, H. (2012). Market relevance of university accounting programs: Evidence from australia. In Accounting Forum, volume 36, pages 91-108. Elsevier.

Parker, S. C. and Van Praag, C. M. (2012). The entrepreneur's mode of entry: Business takeover or new venture start? Journal of Business Venturing, 27(1):31-46.

Pepitone, J. (2010). Twitter users not so social after all. CNNMoney. com.

Plumlee, R. D. and Reckers, P. M. (2014). Lessons not learned: Why is there still a crisis-level shortage of accounting ph. ds? Accounting Horizons, 28(2):313-330.

Ramsden, P. (2003). Learning to teach in higher education. Routledge.

Schleifer, L. L. and Dull, R. B. (2009). Metacognition and performance in the accounting classroom. Issues in Accounting Education, 24(3):339-367.

Schneider, G. P. and Sheikh, A. (2012). Addressing the shortage of accounting faculty: Using non-tenure-track positions. Academy of Educational Leadership Journal, 16(1):1.

Spence, P. R., Westerman, D., Skalski, P. D., Seeger, M., Sellnow, T. L., and Ulmer, R. R. (2006). Gender and age effects on information-seeking after 9/11. Communication Research Reports, 23(3):217-223.
Suddaby, R., Saxton, G. D., and Gunz, S. (2015). Twittering change: The institutional work of domain change in accounting expertise. Accounting, Organizations and Society, 45:52-68.

Sutter, J. (2010). Texts, maps battle haiti cholera outbreak. Retrieved October, 31:2010.

Swain, M. R. and Olsen, K. J. (2011). From student to accounting professional: A longitudinal study of the filtering process. Issues in Accounting Education, 27(1):17-52.

Swanson, D. J. and Creed, A. S. (2014). Sharpening the focus of force field analysis. Journal of change management, 14(1):28-47.

Tan, L. M. and Laswad, F. (2006). Students' beliefs, attitudes and intentions to major in accounting. Accounting Education: an international journal, 15(2):167-187.

Tho, L. M. (1994). Some evidence on the determinants of student performance in the university of malaya introductory accounting course. Accounting Education, 3(4):331-340.

Tognazzo, A., Gubitta, P., and Gianecchini, M. (2016). " my old and my new family"-the impact of family relationships on students' entrepreneurial intentions: An italian study. International Review of Entrepreneurship, 14(4).

Tong, S. T., Van Der Heide, B., Langwell, L., and Walther, J. B. (2008). Too much of a good thing? the relationship between number of friends and interpersonal impressions on facebook. Journal of computer-mediated communication, 13(3):531-549.

Upton, D. R. and Arrington, C. E. (2011). Race matters: whether we know it, or like it, or not: implicit racial attitudes and their effect on accounting-based, balanced scorecard performance evaluations.

Urbano, C., Zhang, Y., Downey, K., and Klingler, T. (2015). Library catalog log analysis in e-book patron-driven acquisitions (pda): A case study. College $\mathcal{E}$ Research Libraries, 76(4):412-426.

Vysotskaya, A., Kolvakh, O., and Stoner, G. (2016). Mutual calculations in creating accounting models: A demonstration of the power of matrix mathematics in accounting education. Accounting Education, 25(4):396-413.

Watson, S. F., Apostolou, B., Hassell, J. M., and Webber, S. A. (2007). Accounting education literature review (20032005). Journal of Accounting Education, 25(1-2):1-58.

Whiston, S. C. and Keller, B. K. (2004). The influences of the family of origin on career development: A review and analysis. The Counseling Psychologist, 32(4):493-568.

Yusuf, M. (2011). The impact of self-efficacy, achievement motivation, and self-regulated learning strategies on students academic achievement. Procedia-Social and Behavioral Sciences, 15:2623-2626.

Zapkau, F. B., Schwens, C., and Kabst, R. (2017). The role of prior entrepreneurial exposure in the entrepreneurial process: a review and future research implications. Journal of Small Business Management, 55(1):56-86. 
Zapkau, F. B., Schwens, C., Steinmetz, H., and Kabst, R. (2015). Disentangling the effect of prior entrepreneurial exposure on entrepreneurial intention. Journal of Business Research, 68(3):639-653. 